\title{
AS NOVAS EXIGÉNGIAS dA COMUNICAÇÃo CIENTÍfICA NA ERA do CONHECIMENTO
}

Isabel Amélia Costa Mendes ${ }^{1}$

Maria Helena Palucci Marziale ${ }^{2}$

Tanto o produto quanto o processo da atividade científica são dependentes de comunicação eficaz. Muitos cientistas e analistas em ciência e tecnologia já se deram conta deste fato, afirmando que não existe ciência sem comunicação ${ }^{(1-6)}$.

Dentre variadas possibilidades de mecanismos para difusão e compartilhamento de resultados da atividade de investigação, hoje disponíveis, tomemos alguns dilemas presentes no cerne e no entorno da publicação científica.

Tradicionalmente as descobertas científicas galgaram reconhecimento e credibilidade mediante sua publicação em revistas especializadas. $O$ alcance dessa meta pressupõe um criterioso processo de avaliação por pares que, no papel de árbitros (referees), asseguram o rigor e a originalidade dos manuscritos submetidos a avaliação ${ }^{(7-8)}$. Ao ultrapassar este processo com êxito e com reconhecimento do seu valor, o texto científico, ora transformando em publicação, representa a consagração desse valor o qual, por sua vez, terá uma variação em função do prestígio do periódico em que foi publicado.

Neste contexto, é fácil deduzir que o prestígio do periódico está intimamente relacionado à qualidade da arbitragem e dos manuscritos submetidos. Estes constituem os indicadores primários de qualidade de um periódico, segundo nossa percepção.

Os indicadores secundários já foram tocados neste espaço em edição anterior ${ }^{(9)} \mathrm{e}$ enquadram-se nos critérios de seleção para indexação em base de dados. Mas os primários são os que devem ser o foco primordial da atenção dos editores científicos e dos referees.

Na subjacência do trabalho desses agentes da editoração científica está uma mudança de paradigma. Segundo consta, a participação militar e da indústria no financiamento da ciência induziu a política de retardamento da divulgação de resultados e até a prática de segredo ${ }^{(1)}$. 0 ritmo da publicação científica, à luz desse paradigma, tinha também dois componentes adicionais: estilo de vida e trabalho dos cientistas e acomodação dos editores aos recursos limitados para esta atividade. Este paradigma é inaceitável na era do conhecimento, que valoriza a rapidez da comunicação pública dos resultados!

Editores da Revista Latino-Americana de Enfermagem da Escola de Enfermagem de Ribeirão Preto, da Universidade de São Paulo, Centro Colaborador da OMS para o desenvolvimento da pesquisa em enfermagem: ${ }^{1}$ Professor Titular, e-mail: iamendes@eerp.usp.br; ${ }^{2}$ Professor Livre-Docente, e-mail: marziale@eerp.usp.br 
A agilidade hoje esperada e já exigida pelos cientistas agudiza o problema da editoração. Particularmente na área da enfermagem os editores científicos precisam contar com referees sintonizados com o paradigma da nova era, comprometidos com os limites temporais e com os indicadores de qualidade que deverão balizar sua fundamental e importante atividade colaborativa para a comunicação científica.

\section{REFERÊNCIAS BIBLIOGRÁFICAS}

1. Barrère M. A ciência na arena pública. In: Witkowski N, coordenador. Ciência e tecnologia hoje. São Paulo (SP): Ensaio; 1995. p.401-2.

2. Latour B. O reino do texto científico. In: Witkowski N, coordenador. Ciência e tecnologia hoje. São Paulo (SP): Ensaio; 1995. p.399-401.

3. Drucker P. The age of social transformation. Atlantic Monthly, November 1994.

4. Toffler A. Powershift: as mudanças do poder. Rio de Janeiro (RJ): Record; 1990.

5. Mendes IAC. Enfermagem, conhecimento e comunicação. Rev Latino-am Enfermagem 1996 abril; 4 ( $n^{\circ}$ especial): $1-2$.

6. Mendes IAC. Criação, divulgação e ação: o saber em movimento. Rev Latino-am Enfermagem 1995 janeiro; 3 $(1): 1-2$.

7. Marziale MHP. O processo de revisão de manuscritos e a melhoria da qualidade das publicações. Rev Latino-am Enfermagem 2001 setembro-outubro; 9(5):1-5.

8. Mendes IAC, Marziale MHP. Avaliação por pares em divulgação científica. Rev Latino-am Enfermagem 2001 novembro-dezembro; 9(6):1-2.

9. Marziale MHP, Mendes IAC. Uma grande conquista: Revista Latino-Americana de Enfermagem ingressa na coleção SciELO. Rev Latino-am Enfermagem 2002 janeiro-fevereiro; 10(1):1-2. 


\section{SCIENTIFIC COMMUNICATION MAJOR REQUIREMENTS IN KNOWLEDGE ERA}

Isabel Amélia Costa Mendes ${ }^{1}$

Maria Helena Palucci Marziale ${ }^{2}$

The product and the scientific activity process are dependent of efficacious communication. Scientists and S\&T analysts are aware of this and affirm that there is no science without communication $^{(1-6)}$.

Among the several possibilities of available mechanisms to disseminate and share research results, there are some dilemmas in the core and permeating scientific publications.

Traditionally, scientific discoveries were recognized and credible as they were published in specialized journals. Therefore, publishing an article presupposes a detailed process of evaluation by experts, acting as referees and assuring the rigour and originality of the manuscripts ${ }^{(7-8)}$. Going through the whole process successfully means to have a scientific text, that was transformed in a publication, recognized for its scientific value that will vary according to the prestige of the journal in which it was published.

In this context, it is easy to infer that the prestige of the periodical is related to the quality of the referees and of the manuscripts submitted. These are, according to our perception, the primary indicators of a journal's quality.

The secondary indicators were mentioned in this space in the last issue ${ }^{(9)}$ and are related to data bases indexation criteria. Nevertheless, editors and referees must focus their attention on the primary indicators.

There is a change of paradigm in the work of these agents. According to some authors, military participation and the industry that financed science induced a policy of delaying the dissemination of results and also keeping them a secret ${ }^{(1)}$. The rhythm of scientific publication, in the light of this paradigm, also had two additional components: the life and work style of scientists and the inertia of editors regarding the limited resources directed to this activity. This paradigm is not acceptable in the knowledge era that emphasizes the rapid communication of results!

The agility that is expected and required by the scientists highlights the editors' concerns.

Particularly in nursing, the scientific editors must count with referees that are tuned with the new era paradigm, committed to temporal limits and quality indicators that must base their fundamental and important collaborative activity to improve scientific communication.

Editors of Latin American Journal of Nursing of Ribeirão Preto of the University of São Paulo at Ribeirão Preto College of Nursing - WHO Collaborating Centre for Nursing Research Development: ${ }^{1}$ Full Professor, e-mail: iamendes@eerp.usp.br; ${ }^{2}$ Associate Professor, e-mail: marziale@eerp.usp.br 


\section{REFERENCES}

1. Barrère M. A ciência na arena pública. In: Witkowski N, coordenador. Ciência e tecnologia hoje. São Paulo (SP): Ensaio; 1995. p.401-2.

2. Latour B. O reino do texto científico. In: Witkowski N, coordenador. Ciência e tecnologia hoje. São Paulo (SP): Ensaio; 1995. p.399-401.

3. Drucker P. The age of social transformation. Atlantic Monthly, November 1994.

4. Toffler A. Powershift: as mudanças do poder. Rio de Janeiro (RJ): Record; 1990.

5. Mendes IAC. Enfermagem, conhecimento e comunicação. Rev Latino-am Enfermagem 1996 abril; 4 ( $n^{\circ}$ especial): $1-2$.

6. Mendes IAC. Criação, divulgação e ação: o saber em movimento. Rev Latino-am Enfermagem 1995 janeiro; 3 $(1): 1-2$.

7. Marziale MHP. O processo de revisão de manuscritos e a melhoria da qualidade das publicações. Rev Latino-am Enfermagem 2001 setembro-outubro; 9(5):1-5.

8. Mendes IAC, Marziale MHP. Avaliação por pares em divulgação científica. Rev Latino-am Enfermagem 2001 novembro-dezembro; $9(6): 1-2$.

9. Marziale MHP, Mendes IAC. Uma grande conquista: Revista Latino-Americana de Enfermagem ingressa na coleção SciELO. Rev Latino-am Enfermagem 2002 janeiro-fevereiro; 10(1):1-2. 


\section{LAS NUEVAS EXIGENCIAS DE LA COMUNICACIÓN CIENTÍFICA EN LA ERA DEL CONOCIMIENTO}

Isabel Amélia Costa Mendes ${ }^{1}$

Maria Helena Palucci Marziale ${ }^{2}$

Tanto el producto como el proceso de la actividad científica dependen de la comunicación eficaz. Muchos científicos y analistas en ciencia y tecnología ya se dieron cuenta de este hecho afirmando que no existe ciencia sin comunicación ${ }^{(1-6)}$.

Dentro de varias posibilidades de mecanismos de difusión e intercambio de resultados de la actividad investigativa hoy disponibles, tomemos algunos dilemas presentes tanto alrededor como en la periferia de la publicación científica.

Tradicionalmente los descubrimientos científicos ganaron reconocimiento y credibilidad mediante su publicación en revistas especializadas. El alcance de esta meta supone un proceso riguroso de evaluación por pares que, en el papel de árbitros, aseguren el rigor y la originalidad de los manuscritos sometidos a evaluación ${ }^{(7-8)}$.

Al sobrepasar este proceso con éxito y con reconocimiento de su valor, el texto científico ya transformado en publicación, representa la consagración de ese valor, el cual, a su vez, tendrá una variación en función del prestigio de la revista en que fue publicado.

En este contexto, es fácil deducir que el prestigio del periódico está íntimamente relacionado con la calidad del arbitraje y de los manuscritos enviados. Estos constituyen los indicadores primarios de calidad de una revista, según nuestra percepción.

Los indicadores secundarios ya fueron referidos en este espacio en una edición anterior ${ }^{(9)}$ y se encuadran en los criterios de selección para indexación en la base de datos. Pero los primarios son los que deben ser el foco primordial de la atención de los editores científicos y de los árbitros.

Subyacente al trabajo de estos agentes de la editoriación científica está el cambio de paradigma. Según consta, la participación militar y de la industria en el financiamiento de la ciencia induce la política de atraso en la divulgación de resultados y hasta la práctica de secreto ${ }^{(1)}$. El ritmo de la publicación científica, a la luz de ese paradigma tenia también dos componentes adicionales: estilo de vida y trabajo de los científicos y acomodación de los editores a los recursos limitados para esta actividad. Este paradigma es inaceptable en la era del conocimiento, que valoriza la rapidez de la comunicación pública de los resultados.

Editores de la Revista Latinoamericana de Enfermería de la Escuela de Enfermería de Ribeirão Preto de la Universidad de São Paulo, Centro Colaborador de la OMS para el desarrollo de la investigación en enfermería: ${ }^{1}$ Profesor Titular, correo electrónico: iamendes@eerp.usp.br; ${ }^{2}$ Profesor Libre-Docente, correo electrónico: marziale@eerp.usp.br 
La agilidad hoy esperada y ya exigida por los científicos agudiza el problema de la editoriación.

Particularmente en el área de enfermería, los editores científicos necesitan contar con árbitros sintonizados con el paradigma de la nueva era, comprometidos con los limites temporales y con los indicadores de calidad que deberán fortalecer su fundamental e importante actividad de colaboración para la comunicación científica.

\section{REFERENCIAS BIBLIOGRAFICAS}

1. Barrère M. A ciência na arena pública. In: Witkowski N, coordenador. Ciência e tecnologia hoje. São Paulo (SP): Ensaio; 1995. p.401-2.

2. Latour B. O reino do texto científico. In: Witkowski N, coordenador. Ciência e tecnologia hoje. São Paulo (SP): Ensaio; 1995. p.399-401.

3. Drucker P. The age of social transformation. Atlantic Monthly, November 1994.

4. Toffler A. Powershift: as mudanças do poder. Rio de Janeiro (RJ): Record; 1990.

5. Mendes IAC. Enfermagem, conhecimento e comunicação. Rev Latino-am Enfermagem 1996 abril; 4 ( $n^{\circ}$ especial): $1-2$.

6. Mendes IAC. Criação, divulgação e ação: o saber em movimento. Rev Latino-am Enfermagem 1995 janeiro; 3 (1):1-2.

7. Marziale MHP. O processo de revisão de manuscritos e a melhoria da qualidade das publicações. Rev Latino-am Enfermagem 2001 setembro-outubro; 9(5):1-5.

8. Mendes IAC, Marziale MHP. Avaliação por pares em divulgação científica. Rev Latino-am Enfermagem 2001 novembro-dezembro; $9(6): 1-2$.

9. Marziale MHP, Mendes IAC. Uma grande conquista: Revista Latino-Americana de Enfermagem ingressa na coleção SciELO. Rev Latino-am Enfermagem 2002 janeiro-fevereiro; 10(1):1-2. 